\title{
GOOD UNIVERSITY GOVERNANCE: BUDGETING PARTICIPATION AND INTERNAL CONTROL
}

\author{
Rulyanti Susi Wardhani ${ }^{1 *}$, Taufiq ${ }^{2}$, Luk Luk Fuadah ${ }^{3}$, \\ Saadah Siddik ${ }^{4}$ and Murtiadi Awaluddin ${ }^{5}$ \\ ${ }^{1}$ Fakultas Ekonomi, Universitas Bangka Belitung, Indonesia. \\ E-mail: rulyantiwardhani67@gmail.com \\ ${ }^{1,3}$ Fakultas Ekonomi, Universitas Sriwijaya, Indonesia \\ ${ }^{4}$ Fakultas Ekonomi, Universitas Muhammadiyah Palembang, Indonesia. \\ ${ }^{5}$ Program Pascasarjan UIN Alauddin, Sulawesi Selatan, Indonesia.
}

\section{ABSTRACT}

The purpose of this study was to examine the simultaneous and partial effects of budgeting participation and internal control on good university governance at Bangka Belitung University and State Manufacturing Polytechnic of Bangka Belitung Islands, Indonesia. Data collection used a saturated sampling method of 485 consisting of all employees and lecturers at the two colleges. Estimation models were built based on previous research studies and the Agency Theory. Data analysis techniques used multiple regression analysis along with testing classical assumptions using a Likert scale on primary data. The results of the study showed that budgetary participation and internal control have a positive and significant effect on good university governance both simultaneously and partially, where internal control is the dominant variable influencing good university governance. This illustrates the alignment of findings with the Agency Theory. The implications for the future are that the Bangka Belitung University and the State Manufacturing Polytechnic continue to pay attention to internal control to create a resonance of good university governance towards the internationalization of higher education. In this study only two variables were used that affect good university governance. Other influences also play a role in the improvement including audit committees, organizational culture, and organizational communication climate that can be addressed by future researchers.

Keywords: good university governance, budgeting participation, internal control

\section{ARTICLE INFO}

Article History:

Received: 30 September 2018

Accepted: 27 February 2019

Published: 30 April 2019 


\section{INTRODUCTION}

Efforts to improve the quality of human resources in realizing full and comprehensive development both in human development and development resources related to ethics, aesthetics, and logic to become a potential are demanded by one of them is a college presence. This condition is by the breath of reforming is a demand to carry out democratization in all fields (Halil, 2017).

Contributions given by universities in each region depend on the innovation of the region so that each region will give a varied contribution (Jonkers, Tijssen, Karvounaraki, \& Goenaga, 2018). Colleges can promote their regional economic development and trust in the community to be involved in regional development (Etzkowitz, 2003; Lendel, 2010; Lester, 2005). This has led to the role of tertiary institutions that is quite large which is to act as a role model and determinant of other world developments, especially economic development. In higher educationvarious ideas will be studied, various theories will be tested, various techniques and methods will be developed, and workers with various types of abilities will be trained (Ali, Ahmad, Ahmad, \& Ali, 2009; Lin, 2004).

As one of the regions or province which is rich in tin as a natural resource while having a high dependence on these tin commodities, wherein 2001-2014 the economic growth rate of the Bangka Belitung Islands Province tended to decline and was still below the Indonesian economic growth rate (BPS, 2015). This situation makes universities especially State Universities in Bangka Belitung namely Bangka Belitung University (UBB) and State Manufacturing Polytechnic (POLMAN) synergize with the local government to build the Bangka Belitung Islands province by improving the quality of PTN. To increase the quality of PTN, one of them is the application of Good University Governance (GUG) by Government Regulation No. 4 of 2014 concerning the organization and management of universities. The application of GUG in UBB and POLMAN is not yet in line with expectations because internal supervision and control are ineffective and existing human resources are inadequate (Inspectorate of Kemenristekdikti, 2016). 
Internal control is effective when the entity's objectives are achieved, the reliability of financial reporting, the security of state assets, and are in compliance with laws and regulations in force (BPK RI, 2015). Management of tertiary institutions is inseparable from the budget because the budget is a guideline or plan that is structured systematically in the form of numbers and expressed in monetary units related to all company activities or organizations for a certain period (Horngren et al., 2010; Shah, 2007).

The budget must be able to accommodate the interests of each unit within the company or organization; therefore, in the preparation of the budget, there needs to be participating so that all interests are fulfilled. Budgeting in higher education involves faculty, study programs, and academics, but the reality of budgeting in higher education only involves a few elements, so the budget is not on target. Budgeting is not well targeted will cause dysfunctional behavior and negative behavior between organizations (Argyris, 1952; Kenis, 1979; Jermias \& Yigit, 2013; Dianthi \& Wirakusuma, 2017). UBB and POLMAN are New State Universities (PTNB) whose budgeting is still patterned with individual systems that do not directly dismiss faculty; faculties only provide input so that the final decision is decided through university leadership meetings.

Empirical research with the theme of GUG is still interesting to study because good university governance is an effort to improve the quality of higher education (Nulhaqim, Heryadi \& Pancasilawan, 2016) and researchers try to review budgetary participation and internal control of higher education governance or GUG. Related to budgeting has been carried out since 1952 (Argyris, 1952). However, this research is still interesting to do now because budgeting participation is generally recognized as a managerial approach that is still relevant because it is believed to influence the behavior and performance of employees involved in the budgeting process (Kusuma, 2016; Lina, 2015). The demands and needs of the globalization era to realize good governance and restore trust both locally, nationally and internationally, are required to take strategic steps with the effectiveness of internal control (Nulhaqim et al., 2016). This study refers to the research of Ebdon, Jiang and Franklin (2016) and Widanaputra and Mimba (2014) that there is no significant influence or relationship between budgetary participation and good governance mechanisms. Then the study of Njanike et al. (2011), Simon, Mahfudnurnajamuddin, Mas'ud and Su'un 
(2016) and Gusnardi (2009) found that internal control influences corporate governance. Based on the phenomenon found and the lack of consistency of previous research, the researchers tried to re-researchers Good University Governance; Participation in Budget Preparation and Internal Control of the Bangka Belitung State University, Indonesia. The originality of this study is that previous research was only partial, namely budgeting participation and internal control of GUG, in this study trying to combine budgetary participation and control of GUG. The focus of this study is to examine the participation of budgeting arrangements for GUG in new state universities. This study also provides views on the participation of budgeting applied in new state universities and the implementation of internal control which is one of the assessments of the Republic of Indonesia Supreme Audit Agency (BPK-RI) on the implementation of the GUG.

\section{LITERATURE REVIEW}

\section{Agency Theory}

Agency theory Jensen and Meckling (1976) is used as a grand theory that states the agency relationship of a contract where one or more (principal) hires another person (agent) to do some services for their interests by delegating some authority to make agent decision. Principal (government) gives regulatory authority to the agent (college management) and provides resources to the agent. As a manifestation of the agent's responsibility to the principal, the agent carries out good governance. Good governance leads to good management, good performance, finally achieving good results in the management of universities (Carson, Ferguson \& Simnett, 2006). Agency theory can also help explain budgetary participation and internal control (Jensen \& Meckling, 1976). Furthermore, this theory can also explore the relationship between budgeting participation, internal control of GUG and contribute ideas related to conceptual limitations rather than the principal agent. Then agency theory can control the existence of information asymmetry that has an impact on the extent to which budgetary participation in subordinates creates budgetary gaps in Chong and Strauss (2017). 


\section{Good University Governance}

According to Shil (2008), Prasinta (2013) and Siswanto and Aldridge (2005), Corporate governance is defined as the system by which corporation is directed and controlled. The corporate governance structure specifies the distribution of rights and responsibilities among different participants incorporation, such as the board, the managers, stakeholders, and other stakeholders and spells out of the rules and procedures and for making the decision on corporate affairs. By doing this, it also provides the structure through which the company objectives are set and the means of attaining those objectives and monitoring performance.

Another opinion states that Corporate Governance (CG) is a process that is inseparable from the company's goals, and those objectives are determined, measured and pursued in the form of social context, regulations, and commercial environment. For this reason, an effective CG mechanism includes monitoring the actions, policies, and decisions of the company and their partners. However, another way to improve CG is to align the interests of management and stakeholders (Organization for Economic Cooperation and Development (OECD), (2004); Jamaludin and Hashim (2017). The same thing with universities is inseparable from policy and rules so that managerial interests are aligned with stakeholders so that we can look at simple governance good university as the application of the basic principles of the concept of good governance in systems and governance processes in higher education institutions (Salmi, 2009). According to Hénard and Mitterle (2010); Zaman (2016) one of the rationales is the implementation of good university governance will be able to protect institutions from fraud or mismanagement by holders of autonomy rights and able to provide suggestions for improvement. The principles of GUG are governance structure, autonomy, accountability, leadership, transparency (Kohler, 2006; Hénard \& Mitterle, 2010; Burke, 2005; Pestoff \& Hulgard, 2015; Martini, Sari \& Wardhani, 2015).

\section{Internal Control}

According to Abbott Parker and Peters (2012), Lingle and Schiemann (1996) and Agustina and Riharjo (2016) control is the process of motivating and encouraging members of the organization to carry out organizational 
activities and achieving organizational goals. Definition of internal control issued by the International Organization of Supreme Audit Institutions (2004) stated:Internal control is an integral process that is effected by an entity's management and personnel and is designed to address risks and to provide reasonable assurance that in pursuit of the entity's mission, the following general objectives are being achieved: a) executing orderly, ethical, economical, efficient and effective operations; b) fulfilling accountability obligations; c) complying with applicable laws and regulations; d) safeguarding resources against loss, misuse and damage. The internal control concept issued by COSO, states that internal control consists of policies and procedures designed to provide management with reasonable certainty that the organization has achieved its goals and objectives. These policies and procedures are often called controls, and collectively form the entity's internal controls (Arens, Randal \& Beasley, 2012). The components of internal control consist of the control environment, risk assessment, control activities, information \&communication and monitoring (Arens et al., 2012).

\section{Budgeting Participation}

The budget has a role as planning, and as a performance criterion, namely, the budget is used as a control system to measure managerial performance. The key to effective performance is when the objectives of the budget are achieved. In budgeting, it is inseparable from budget participation involving managers in determining budget goals the responsibility (Brownell, 1983; Chin-Chun \& Feng-Yu, 2013). According to Sundari, Hamid Habbe \& Mediaty (2016), Brownell and McInnes (1986) and De Baerdemaeker and Bruggeman (2015) that participation in budgeting is the breadth of managers involved in budget preparation and the magnitude of the influence of managers on organizational unit goals which is their responsibility. Participation in budgeting is related to the role and benefits of Chong and Chong (2002), Ardianti (2015) and Asak, Yasa and Astika (2016), among others: 1) the role of subordinates when programs and activities are arranged, 2) the role of subordinates when the budget for programs and activities prepared, 3 ) the existence of proposals or opinions on the budget, 4) the magnitude of the influence reflected in the final budget, 5) the existence of roles can clarify the goals or objectives to be achieved, 6) there are commitments as part of the organization and 7) existence influence on performance. 


\section{RESEARCH DESIGN}

The research method used in this study is explanatory research because it is a study that explains causal relationships between variables (Cooper $\&$ Schindler, 2014). The unit of analysis of this study is PTN in Bangka Belitung namely POLMAN and UBB. Respondents in this study were lecturers and employees totaling 485 and conducted at the beginning of 2018. The data used were primary data with a Likert scale in the form of questionnaires and the samples used were census, all employees in UBB and Polman were respondents. Data testing is done by validity and reliability test and the analysis technique used is multiple regression analysis. The variables in this study consisted of independent variables namely budgeting participation and internal control and the GUG dependent variable.

The variables in this study are based on theoretical and empirical ones which will be developed into models and hypotheses. The relevant research results in this study include: Gina, Adeghe and Kingsley (2014) that the active role of internal audit is needed in the implementation of good corporate governance, as well as research by Risma, Sri and Nurhayati (2014) and Jaya, Muslim and Nuramaliah (2016), Njanike et al. (2011), Simon et al. (2016) and Gusnardi, (2009) that internal control influences good university governance supported by research. Then the research of Amilin (2016), Ebdon, Jiang, \& Franklin, (2016) and Widanaputra \& Mimba (2014) states that budgetary participation has not been able to encourage the implementation of GUG. By theory and research beforehand, the research model can be drawn as follows:

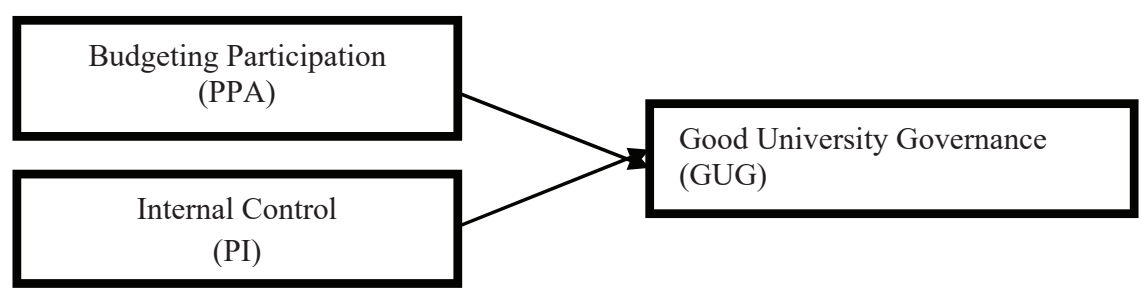

Figure 1: Research Model

Based on the theory and previous studies the regression equation model of this study is as follows: 


$$
\mathrm{GUG}=\mathrm{f}(\mathrm{PPA}, \mathrm{PI})
$$

This function will produce the GUG equation model as follows:

$$
G U G=\alpha+\beta_{1} P P A+\beta_{2} P I+\varepsilon
$$

Where; GUG (Good University Governance), PPA (Budgeting Participation), PI (Internal Control), $\alpha$ (constants), $\beta$ (Regression coefficient) and $\varepsilon$ (Other factors that influence GUG).

\section{RESULTS AND DISCUSSION}

\section{Results}

The questionnaire distributed was 485 respondents who spread it via email, field surveys, and google form via the WhatsAppp link. The returned questionnaire was only 396 because there were 89 respondents who were incomplete and unwilling to fill, so that the data analyzed were 396 respondents, descriptive UBB and Polman employees based on Table 1:

Table 1: Descriptive Analysis

\begin{tabular}{|c|c|c|c|c|c|c|c|c|}
\hline \multicolumn{2}{|c|}{ Gender } & \multicolumn{2}{|c|}{ Employee Status } & \multicolumn{5}{c|}{ Education } \\
\hline Male & Female & $\begin{array}{c}\text { Civil } \\
\text { Servant }\end{array}$ & $\begin{array}{c}\text { Non-Civil } \\
\text { Servant }\end{array}$ & $\begin{array}{c}\text { Senior } \\
\text { High } \\
\text { School }\end{array}$ & Diploma & Bachelor & Master & Doctor \\
\hline 234 & 162 & 90 & 306 & 41 & 57 & 64 & 215 & 19 \\
\hline $59.1 \%$ & $40.9 \%$ & $77.3 \%$ & $22.7 \%$ & $10.4 \%$ & $14.4 \%$ & $16.2 \%$ & $54.2 \%$ & $4.8 \%$ \\
\hline
\end{tabular}

Source: processed data, 2018

Table 1 explains that UBB and POLMAN employees are based on male-dominant sex as many as 59.1 percents compared to women at 40.9 percent. For non-Civil Servants dominant employees, 77.3 percent and the remaining 22.7 percent are Civil Servants. While the majority of the Master education is 54.2 percent and the low academic level is the Undergraduate program. However, the leaders of UBB and POLMAN continue to increase human resources to a higher level and fight for the status of employees and lecturers that are not yet clear because of the differences between non-civil 
servants and civil servants, making the performance of these universities decline.

The results of the validity test show that the Spearman correlation coefficient for each question item, both the budgeting participation variable, internal control, and good university governance, yields a smaller value than the Spearman correlation value and each item is valid so that it is worth using to collect research data. The reliability test results using the Cronbach alpha $(\alpha)$ technique, where an instrument can be said to be reliable if it has Cronbach alpha greater than 0.60 . Reliability test results indicate that each instrument used in this study has a Cronbach alpha value of 0.814 . This indicates that the instrument used is a good reliability value.

Table 2: Mulitple Regression Analysis

\begin{tabular}{lcccc}
\hline Model & Coefficient & t & Sig. & $\begin{array}{c}\text { Collinearity } \\
\text { Statistics } \\
\text { VIP }\end{array}$ \\
\hline Constant & 15.392 & 4.697 & 0.000 & \\
PPA & 0.205 & 4.521 & 0.000 & 1.027 \\
PI & 0.617 & 13.967 & 0.000 & 1.027 \\
\hline
\end{tabular}

CorrelationCoefficient $(R)=0.581$

DeterminationCoefficient $\left(R^{2}\right)=0.338$

$\mathrm{F}=100.157(\mathrm{Sig}=0.000)$

Source: processed data, 2018

Based on Table 2 above, the equations from this study are as follows:

$$
G U G=15.392+0.205 P P A+0.617 P I+\varepsilon
$$

The results of this study illustrate the correlation coefficient of 0.581 , which means that the budget preparation and internal control have a close relationship with good university governance with a value of 0.581 or $58.1 \%$. This means that $58.1 \%$ of good university governance variables can be explained by the variable budgeting participation and internal control while the remaining $41.9 \%$ is explained by variables or other factors not included in this research model. Simultaneously budget participation and internal control have a positive and significant effect on good university 
governance. This is indicated by the $\mathrm{F}_{\text {count }}$ value of 100.157 and compared with $\mathrm{F}_{\text {table }}$ of 1.181 where the rule is that if $\mathrm{F}_{\text {count }}>\mathrm{F}_{\text {table }}$ will have an effect.

The results of the t-test indicate that the variable budgeting participation and internal control also have a positive and significant effect on the good university governance variable. This is indicated by the value of $\mathrm{t}_{\text {count }}$ of 4.521 and $t_{\text {table }}$ of 1.966 for the budgeting participation variable while the internal control variable $t_{\text {count }}$ at 13.967 with the method if the $t_{\text {table }}<t_{\text {count }}$ will affect.

\section{DISCUSSION}

\section{The Effect of Budgeting Participation on Good University Governance}

The test results show there is a positive and significant influence between budgeting participation on GUG in UBB and POLMAN PTN in the Bangka Belitung Islands Province, Indonesia. This means that the higher the budgetary participation, the effect of GUG in UBB and POLMAN PTN will be realized. Budgeting participation is the involvement of managers (both staff, lecturers and leaders) in an institution to carry out activities in achieving the targets set in the budget. The involvement will stimulate staff, lecturers and leaders to be responsible for each task given so that the GUG resonance in higher education will be achieved through budgetary participation which is expected toaccommodate all requests for budgets from the lower level to the top and consider aspirations from below.

The results of this study contradict the research of Ebdon, Jiang, and Franklin, (2016), Widanaputra and Mimba (2014) and Amilin, 2016) which found that there was no influence between budgetary participation on good governance, while the findings from the results of this study that there is an influence of budgeting participation on GUG. The causal factor is that UBB and POLMAN in budgeting have involved staff and lecturers in realizing GUG resonance (implementation) through budgetary participation indirectly the GUG principle has been implemented such as transparency, accountability has been applied. Then between the government (principal) and the management of higher education (agents) in budgeting participation is authorized to welcome the resonance of GUG, in other words, this research 
supports the agency theory presented by Jensen \& Meckling (1976) and supported by Carson's opinion, Ferguson, and Simnett (2006).

\section{The Effect of Internal Control on Good University Governance}

The results of the tests show that there is a positive and significant influence between internal control of GUG at PTN in UBB and POLMAN in Kepulauan Province, Bangka Belitung, Indonesia. This means that the better internal control, the more GUG resonance can be realized in UBB and POLMAN.

UBB and POLMAN as public education institutions in the Province of Bangka Belitung Islands, encourage to maximize adequate internal control due to the desire to do good organization management. Based on the results of the study that the implementation of internal control will both increase the resonance of GUG. Besides that, the aggregation of the unification of internal control and organizational commitment as a picture played by existing unit leaders and all of its staff has encouraged the design and improvement of service delivery, especially in the manifestation of tri dharma in UBB and POLMAN. The many obstacles faced in realizing the effectiveness of this internal control, but does not hinder the way of GUG resonance in UBB and POLMAN. The findings of this study are in accordance with agency theory Jensen \& Meckling (1976), and support the research of Njanike et al. (2011), Simon et al. (2016) and Gusnardi, (2009), Gina, Adeghe and Kingsley (2014) Risma, Sri and Nurhayati, (2014) and Jaya, Muslim and Nuramaliah, (2016) found that internal control affects corporate or organizational management.

\section{CONCLUSIONS AND RECOMMENDATIONS}

The conclusion that can be obtained in this study is that budgetary participation and internal control simultaneously influence the GUG in UBB and POLMAN in the Bangka Belitung Islands, Indonesia. Fragmentary, each variable, namely budgeting participation variable and internal control variable has a positive and significant effect on GUG in UBB and POLMAN in Bangka Belitung Islands, Indonesia. The dominant variable affecting GUG in this study is internal control. 
Suggestions for this research are expected in future studies to develop variables that influence GUG that are not examined such as organizational culture, internal audit, organizational commitment and expanding the object of research so that it can compare New State Universities (PTNB) with established universities and analysis tools which are used such as comparing new and established universities and comparing universities outside of Sumatra. Practically in particular UBB and POLMAN so that the higher education leaders commit and synergize with their subordinates to carry out the resonance of GUG in leading internationalized universities. There is support from the government, especially the Ministry of Research, Technology and Higher Education of the Republic of Indonesia, to always pay attention to PTNB's special universities because of the transfer of status from the private sector to the country whose the governance is not optimal.

\section{REFERENCE}

Arens, A., Randal, E., \& Beasley, M. S. (2012). Auditing and Assurance Services: An integrated approach. $\left(14^{\text {th }}\right.$ ed.). Upper Saddle River: Pearson.

Abbott, L. J., Parker, S., \& Peters, G. F. (2012). Internal audit assistance and external audit timeliness. Auditing, 31(4), 3-20.

Agustina, G. P., \& Riharjo, I. B. (2016). Faktor-faktor yang mempengaruhi kelemahan pengendalian intern pemerintah daerah. Jurnal Ilmu Dan Riset Akuntansi, 5(4), 1-15.

Ali, H., Ahmad, L., Ahmad, S., \& Ali, N. (2009). Keperluan, kepentingan dan sumbangan perancangan pendidikan dalam pembangunan ekonomi Malaysia. Jurnal of Social Sciences and Humanities, 4(1), 13-29.

Amilin. (2016). Dampak penerapan good university governance terhadap kinerja manajerial melalui implementasi anggaran berbasis partisipatif. Jurnal Akuntansi Universitas Tarumanagara, 20(3), 330-344.

Ardianti. (2015). Pengaruh penganggaran partisipatif pada budgetary slack dengan asimetri informasi, self esteem, locus of control dan kapasitas 
individu sebagai variabel moderasi (Studi pada SKPD Kabupaten Jembrana, Bali). E-Jurnal Ekonomi Dan Bisnis Universitas Udayana, 4(5), 296-311.

Argyris. (1952). Organizational leadership and participation management. The Journal Of Business, 28(1), 1-7.

Asak, P. R. A., Yasa, G. W., \& Astika, B. I. P. (2016). Kemampuan asimetri informasi, ketidakpastian lingkungan, budget emphasis, dan kapasitas individu sebagai variabel moderasi terhadap partisipasi anggaran pada budgetary slack. E-Jurnal Ekonomi Dan Bisnis Universitas Udayana, 5(2), 219-228.

BPK RI. (2015). Ikhtisar Hasil Pemeriksaan Semester.

BPS. (2015). Provinsi Kepulauan Bangka Belitung Dalam Angka.

Brownell, P. (1983). Leadership style, budgetary participation and managerial behavior. Accounting, Organizations and Society, 8(4), 307-321.

Brownell, P., \& McInnes, M. (1986). Budgetary participation, motivation, and managerial performance. Accounting Review, 61(4), 587.

Burke, J. C. (2005). The many faces of accountability. In J. C. Burke Et al. (Eds.), Achieving accountability in higher education: Balancing public, academic, and market demands (pp. 1-24). San Francisco: Jossey-Bass.

Carson, E., Ferguson, A., \& Simnett, R. (2006). Australian audit reports: 1996-2003. Australian Accounting Review, 16(40), 89-96.

Chin-Chun, S., \& Feng-Yu, N. (2013). Budgetary participation and slack on the theory of planned behavior. International Journal of Organizational Innovation, 5(4), 91-100.

Chong, V. K., \& Chong, K. M. (2002). Budget goal commitment and informational effects of budget participation on performance: A structural equation modeling approach. Behavioral Research in Accounting, 14(1), 65-86. 
Chong, V. K., \& Strauss, R. (2017). Participative budgeting: The effects of budget emphasis, information asymmetry and procedural justice on slack - Additional evidence. Asia-Pacific Management Accounting Journal, 12(1), 181-220.

Cooper, D. R., \& Schindler, P. S. (2014). Business research methods. New York, NY: McGraw Hill.

De Baerdemaeker, J., \& Bruggeman, W. (2015). The impact of participation in strategic planning on managers' creation of budgetary slack: The mediating role of autonomous motivation and affective organisational commitment. Management Accounting Research, 29, 1-12.

Dianthi, I. A. G. P., \& Wirakusuma, M. G. (2017). Pengaruh partisipasi penganggaran, asimetri informasi, budaya organisasi dan komitmen organisasi pada senjangan anggaran. E-Jurnal Akuntansi Universitas Udayana. 18(2), 874-901.

Ebdon, C., Jiang, Y., \& Franklin, A. L. (2016). Elected officials' perceptions of governance relationships and budget participation mechanisms. Journal of Public Budgeting, Accounting \& Financial Management, 28(1), 103-124.

Etzkowitz, H. (2003). Innovation in innovation: The Triple Helix of university-industry-government relations. Social Science Information Sur Les Sciences Sociales, 42, 293-337.

Jamaludin, M. F., \& Hashim, F. (2017). Corporate governance, institutional characteristics, and director networks in Malaysia. Asian Academy of Management Journal of Accounting and Finance, 13(132), 135-154.

Gina, O., Adeghe, R., \& Kingsley, O. O. (2014). Internal control as a potential instrument for corporate governance. IOSR Journal of Economics and Finance (IOSR-JEF), 2(6), 66-70.

Gusnardi. (2009). Pengaruh peran komite audit, pengendalian internal, audit internal dan pelaksanaan tata kelola perusahaan terhadap pencegahan kecurangan. Jurnal Akuntansi, 15(1), 137. 
Halil, H. (2017). Peran perguruan tinggi dalam pembangunan daerah. STAI Miftahul Ulum Panyepen Pamekasan.

Hénard, F., \& Mitterle, A. (2010). Governance and quality guidelines in higher education: A review of governance arrangements and quality assurance guidelines. Paris: OECD.

Horngren, C. T., Foster, G., Datar, S. M., Rajan, M., Ittner, C., \& Baldwin, A. A. (2010). Cost accounting: A managerial emphasis,. Issues in Accounting Education, 25(4), 789-790.

Inspektorat Kemenristekdikti. (2016). Materi Temuan di Inspektorat Jenderal. Jakarta.

Jaya, T. E., Muslim, \& Nuramaliah. (2016). Internal control, total quality management and audit committees: Implementation of good corporate governance. Review of Integrative Business and Economics Research, 5(2), 250-260.

Jensen, M. C., \& Meckling, W. H. (1976). Theory of the firm: Managerial behavior, agency costs and ownership structure. Journal of Financial Economics, 3(4), 305-360.

Jermias, J., \& Yigit, F. (2013). Budgetary participation in Turkey: The effects of information asymmetry, goal commitment, and role ambiguity on job satisfaction and performance. Journal of International Accounting Research, 12(1), 29-54.

Jonkers, K., Tijssen, R., Karvounaraki, A., \& Goenaga, X. (2018). A Regional Innovation Impact Assessment Framework for universities. JRC Discussion Paper. Retrieved from http://publications.jrc.ec.europ a.eu/repository/bitstream/JRC109020/jrc109020_iiu27.pdf

Kenis, I. (1979). Effect on budgetary goal characteristic on managerial attitudes and performance. The Accounting Review, 54(4), 707-721.

Kohler, J. (2006). Higher education governance - Background, significance and purpose. In J. Kohler \& J. Huber (Eds.), Higher education 
governance between democratic culture, academic aspirations and market forces (pp. 17-32). Strasbourg: Council of Europe Publishing.

Kusuma, H. B. (2016). Pengaruh partisipasi penyusunan anggaran terhadap kinerja manajerial: Komitmen organisasi sebagai variabel mediasi. Jurnal Akuntansi, 8(2), 203-213.

Lendel, I. (2010). The impact of research universities on regional economies: The concept of university products. Economic Development Quarterly, 24(3), 210-230.

Lester, R. K. (2005). Universities, innovation, and the competitiveness of local economies: A summary report from the local innovation systems project - Phase I. (MIT Industrial Performance Center Working Paper 05-010). Retrieved from https://www.files.ethz.ch/isn/285 09/ LIS05-005.pdf

Lina, L. (2015). Partisipasi penyusunan anggaran, psychological capital, dan kinerja manajerial. Jurnal Manajemen Teknologi, 14(3), 301-320.

Lingle, J. H. \& Schiemann, W. A. (1996). From balanced scorecard to is measurement. American Management Association, 85(3), 56-61.

Martini, R., Sari, K. R., \& Wardhani, R. S. (2015). Analisis penerapan good university governance melalui efektivitas pengendalian intern dan komitmen organisasional. Paper presented at the Simposium Nasional Akuntansi, Medan. Retrieved from https://www.academia.edu/16469 064/Transparansi_dan_Good_University_Governance

Njanike, K., Mutengezanwa, M., \& Gombarume, F. B. (2011). Internal controls in ensuring good corporate governance in financial institutions. Annals of the University of Petroşani Economics, 11(1), 187-196.

Nulhaqim, S. A., Heryadi, D., \& Pancasilawan, R. (2015). Peranan perguruan tinggi dalam meningkatkan kualitas pendidikan Indonesia untuk menghadapi Asean community 2015: Studi kasus Universitas Padjadjaran. Share: Social Work Jurnal, 6(2), 154-272. 
Organisation For Economic Cooperation And Development (OECD). (2004). OECD principles of corporate governance.

Prasinta, D. (2013). Pengaruh good corporate governance terhadap kinerja keuangan. Accounting Analysis Journal, 2(2), 1-14.

Risma, J. S., Sri, F., \& Nurhayati. (2014). Prosiding Akuntansi ISSN: 24606561. Proseding Akuntansi, 6561.

Salmi, J. (2009). The Challenge of Establishing World-Class Universities. In The World-Class University as Part of a New Higher Education Paradigm: From Institutional Qualities to Systemic Excellence (pp. $1-41)$.

Shah, A. (Ed.).(2007). Local budgeting: Public sector governance and accountability series. Washington, USA: TheWorld Bank.

Shil, N. C. (2008). Accounting for good corporate governance. Journal of Administration \& Governance, 3(1), 22-31.

Simon, Y., Mahfudnurnajamuddin, Mas'ud, M., \& Su'un, M. (2016). The role of apparatus competence, internal control system on good governance and the quality of financial statement information. Researchers World Journal of Arts, Science \& Commerce, 7(4), 123-133.

Siswanto, S., \& Aldridge, E. J. (2005). Good Corporate Governance. Jakarta: P.T. Damar Mulia Pustaka.

Sundari, S., Hamid Habbe, A., \& Mediaty. (2016). The relation among budgetary participation and budgetary slack with organizational commitment and leadership style as moderating variable. IOSR Journal of Business and Management Ver. VII, 18(10), 2319-7668.

Widanaputra, A. A., \& Mimba, N. P. S. H. (2014). The influence of participative budgeting on budgetary slack in composing local governments' budget in Bali province. Procedia - Social and Behavioral Sciences, 16, 391-396. 
Asia-Pacific Management Accounting Journal, Volume 14 Issue 1

Zaman, K. (2015). Quality guidelines for good governance in higher education across the globe. Pacific Science Review B: Humanities and Social Sciences, 1(1), 1-7. 